\title{
45
}

\section{Das Immunsystem (Silbenrätsel)}

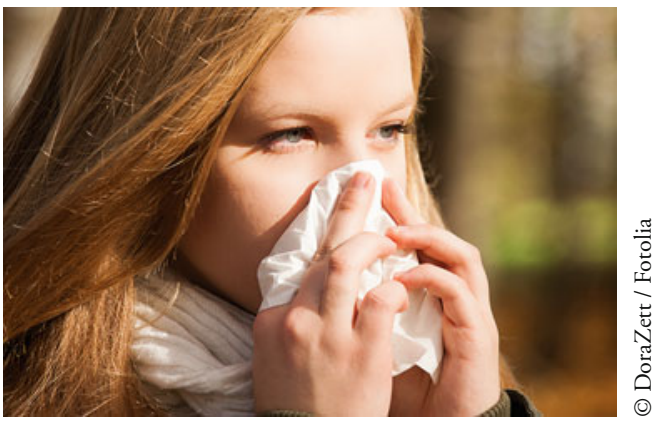

Auch die kleinsten Angreifer müssen abgewehrt werden. Zum Glück besitzen wir ein raffiniertes Immunsystem! Finde die gesuchten Begriffe, indem du die Silben richtig miteinander kombinierst.

\section{Die Silben}

al - an - cy - cyt - e - fak - fung - gen - gie - imp - ko - kör - ler

leu - mak - per - pha - rhe - ro - ro - rus - ryth - sus - ten - ti - tor - vi

\section{Hinweise}

(1) Fresszellen

(2) weiße Blutkörperchen

(3) Partikel mit DNA oder RNA als Erbsubstanz

(4) Antigen der roten Blutkörperchen, das auch bei Rhesusaffen vorkommt

(5) Überreaktion des Immunsystems auf ein normalerweise harmloses Antigen

(6) rotes Blutkörperchen

(7) Immunisierung durch gezielte Übertragung eines Antigens

(8) Y-förmiges Immunglobulin, welches von Plasmazellen produziert wird

1.

2.

3.

4.

(C) Springer-Verlag Berlin Heidelberg 2016

C. Reinbold, Fetthenne, Moderlieschen, Warzenbeißer,

DOI 10.1007/978-3-662-52817-4_45
5.

6.

7.

8. 